\section{The Native Tribes of Western Australia.}

A $\mathrm{T}$ a meeting of the Royal Anthropological Institute on April 13, Sir Everard im Thurn, president, in the chair, Mr. G. O. Neville read a paper on "The Aborigines of Western Australia: Their Treatment and Care." In introducing the speaker, the president laid stress upon the importance of papers dealing with the practical side of native questions. It was often said that the Government did not assist scit'ntifio societies enough, but he was sometimes in doubt whether scientific societies on their side: gave sufficient assistance to the Gevernment.

Mr. Neville said that the aborigines of Western Australia were most numerous in the north, diminishing as they came nearer civilisation, until almost extinct where the white man has lived since the early days of occupation. By nature a nomadic race, they live by hunting alone and cultivate nothing. They communicate with each other by means of a cipher, intelligible only to themselves, cut upon message sticks, or Bambarro, the bearer of which is granted a safe? passage through l:ostile tribes. Numbers of crude figures, representations of beasts, birds, or reptiles, are to be found drawn in coloured pirments upon flat rocks or inside caves in the far north. The gradual disappearance of the natives continues unceasingly, in spite of constant effort. This is due to change of food, their hunting-srounds being occupied by the squatter, and the necessity for their having to clothe themselves and live more or less under shelter. The aborigines do not believe that any person dies a natural death, but suppose the deceased to have been boulyaed (bewitched) by some member of another tribe, and it becomes the duty of a near relative, generally a brother of the dead person, selected by the Bulyas or medicine-men, to avenge his death bv killings the supposed murderer or another one of the tribe to which the murderer is supposed to belong. One of the most remarkable means of disposing of the dead, known as the stone system, occurs in the north. There the body of the dead person is elevated to a platform of sticks built in a tree, a laver of large stones being placed immediately beneath the body. The stones represent individuals who might have caused the death of the victim; and if the fat from the body, evaporating in the heat of the sun, falls upon any stone, the individual represented by that stone is the one unon whom vengeance will sooner or later fall at the hands of the near relatives of the deceased person. If no fat falls, a near relative will, after the removal of the body to an adjacent ant-heap, where only the bones are soon remaining. sleep upon the pile, and it will be revealed to him in a dream which is the selected stonc.

No native can be minloved except under a permit issued by a Protector. Generally speaking, the treatment of Western Australian natives at the hands of their emplovers leaves little to be desired. The Aborigines Act provides the necessary machinery for bringing offenders to book. The Chief Protector being constituted by law the legal guardian of every aboriginal and half-caste child until the age of sixteen, it is possible to remove any child from undesirable surroundings. Some eighty Protectors, under the Chief Protector, are resident in various parts of the State where there are natives. Seventy Government relief stations provide assistance for indigent and destitute natives. The Department orwns cattle settlements in Kimberlev, and two farming and industrial settlements have been established recently in the south for the reception of indigent and aged neople, with snecial provision for the care and training of orphan children. The reserves upon which these settlements NO. 2634 , VOL. IO5] are established are for the natives only, and whites, other than the staff employed, are rigidly excluded by law. The provision of medical attendance has been the special care of the State; all natives receive free advice, medicine, and hospital treatment in case of sickness. The nine mission stations in Western Australia, nearly all subsidised by the State, have done useful work, especially in the care and rescue of children. Though the people are dwindling away, the work of the Department must go on, in the hove that the last days of a dying race can be made the easier and harpier.

In declaring the subject onen for discussion, the president said that the cause of the decrease in a native population when it came into contact with civilisation was its failure to adapt its psychological constitution to changed circumstances.

I)r. Cornev said that as a result of his experience in dealins with immigrant labour-- male only--in Fiji. he had arrived at the conclusion that the trve of soil had an important effect on rertain sroups; for instance, an alluvial soil was fatal to Gilhert Islanders and Solomon Islanders, although the former throve on sandy soil such as that of the islands on which coconuts were grown, and the latter made: excellent sailors. It was also evident that all were peculiarly susceptible to the attacks of micro-organisms from which the European ponulation was to some extent immune. as shown by the virulence of the epidemics of measles and influenza.

Mr. N. W. Thomas pointed out that Pater Schmidt has shown that in the north mode of burial and language coincide in distribution, and asked whether the distribution of drawings also coincided with platform burial and language.

Prof. Arthur Keith said that if we were nlaced in the Australian desert and asked to live the life of the aborigines, he doubted whether we would survive. Would we not rather die as thev die in our environ. ment? When they were brought into contact with our civilisation we asked them to make a jumn of perhaps two thousand generations within a lifetime: to change at once from the life of a prince to that of rivilisation, the life of a horse in a mill. 'The governing factor in deciding the fate of native populations lav in the domain of psychologv. Here the man of science came into touch with the practical problem, for he was trying to understand the back of the black man's mind.

Miss Freire-Marreco compared the measures adopted in Western Australia with those which had been followed in the United States of America, especially in relation to the dying out of the native races. Until about ten vears ago the native races there had diminished ranidly. Since then, however, the Indian population had been on the un-grade, owing largely to the attention paid by the Central Government to the food-supply and the checking of tuberculosis and other diseases by isolation and the inculcation of sanitary and hygienic rules.

\section{University and Educational Intelligence.}

Mr. F. A. Heron has given to Queen's University, Belfast, the sum of 5 onol. to provide the necessary equipment for teaching physical chemistry, and Ioni. towards the provision of accommodation for the department.

In connection with the faculty of medicine of the Eniversity of Birmingham, a course of ten weekly lectures (free to medical men) on "Principles of Psychotherapy" is to be given by Dr. W. 